\title{
HOW PUBLICATION ON THE RESEARCH SKILLS DEVELOPMENT FRAMEWORK AS USEFUL EVIDENCE FOR ACADEMICS WORKING DURING PANDEMIC DISRUPTION
}

\author{
Normuslim(1), Ahmad ${ }^{2)}$, Nur Arif Nugraha'), Dayan Abdurrahman ${ }^{4}$ ) \\ ${ }^{1}$ IAIN Palangkaraya, Indonesia \\ Coresponding author: nor_muslim65@yahoo.com \\ ${ }^{2}$ Universitas Alkhairaat Palu, Indonesia \\ ahmadsajale@gmail.com \\ ${ }_{3}^{3}$ Politeknik Keuangan Negara STAN, Indonesia \\ nur.nugraha@pknstan.ac.id \\ ${ }^{4}$ STKIP An-nur Nanggroe Aceh Darussalam, Indonesia \\ dayanbintang@yahoo.com
}

\begin{abstract}
Abstrak
Penelitian ini mengkaji tentang beberapa publikasi tentang manfaat penerapan Kerangka Pengembangan Keterampilan Riset (RSD) sebagai bukti bagi sivitas akademika dan mahasiswa di jenjang perguruan tinggi dalam melaksanakan tugas yang melibatkan kegiatan pembelajaran berbasis penelitian dan karya ilmiah lainnya. Pakar pembelajaran perguruan tinggi percaya bahwa belajar dan bekerja pada mode jarak jauh, terutama pada gangguan pandemi, sangat terbantu dengan mengembangkan penerapan keterampilan penelitian. Makalah ini telah mendapatkan bukti dari 10 publikasi ilmiah tentang kerangka RSD dan literatur pembelajaran berbasis penelitian lainnya untuk mendapatkan perspektif dan pemahaman yang lebih baik untuk membuktikan asumsi ini. Dengan bukti penelitian yang ada dari tujuh materi publikasi, kita dapat mengatakan bahwa bukti dari publikasi dan keuntungan kerangka kerja Pengembangan Keterampilan Penelitian bersifat konstruktif bagi akademisi dan mahasiswa di universitas di mana keterlibatan keterampilan penelitian yang kaya sangat tinggi dan spesifik karena mereka sekarang bekerja. dalam sistem terpencil selama krisis pandemi yang terinfeksi. Oleh karena itu, kami sangat merekomendasikan akademisi, pelajar di lingkungan pendidikan tinggi. Selain itu, semakin banyak peneliti di luar akademisi yang mengkaji ulang kerangka konseptual dan matriks rubrik penilaiannya dalam karya ilmiah mereka untuk keperluan publikasi atau penandaan internal universitas dalam penyelidikan masa depan.

Kata Kunci: Kerangka Pengembangan Keterampilan Riset, Bekerja jarak jauh, Gangguan Pandemi.
\end{abstract}

\begin{abstract}
This study reviewed some publications on the benefits of implementing the Research Skills Development (RSD)Framework as evidence for academicians and students at the higher education level in carrying out assignments involving research-based learning activities and other scientific work. Higher education learning experts believe that learning and working at a distance mode, especially in the pandemic disruption, is greatly assisted by developing research skills application. This paper has reviewed many scientific publications of the RSD framework and other research-based learning literature to gain a better perspective and understanding to prove this assumption. With the existing research evidence from seven publication materials, we could say that the evidence from the Research Skill Development framework's publicatios and advantages are constructive for academic and students in universities where the involvement of rich research skills is very high and specific as they now are working in the remote system during the crisis of infected pandemic. Therefore, we highly recommend academicians, students in the bigher education environment. In addition, more researchers outside academia to restudy the conceptual framework and its assessment rubric matrix in their scientific work. for publication or internal university marking purposes in future investigation.
\end{abstract}

Keywords: Research Skills Development Framework, Working remotely, Pandemic Disruption 


\section{INTRODUCTION}

There are three main activities of academics that are widely known: the Three Pillars of Higher Education; teaching, research, and community service contribution. (Jongbloed et al., 2008; Tight, 2012; Mainardes, 2009). Teaching assignments are easy to understand because it is in the classroom between students and teachers. This second pillar is often understood in a limited context, namely researching to study something for which there is no answer yet. However, if understood externally, research activities are meant to learn something based on large projects, but efforts to find out something simple by involving the movement of looking for something to answer problems such as in daily learning activities also means research or researchbased learning and teaching. So, as the research work becomes an obligation for every academic community, be involved in research activities and communicate their research results to fellow academics and industry, including state officials, as most academicians cannot entirely do public policymaking.

Unfortunately, this research activity has not received particular attention in the academic environment, especially the theoretical background in higher education in countries whose educational bases are still in the traditional way of thinking and learning. Broekkamp and van HoutWolters, (2007), Akkerman and Bakker, (2011), said that the academic community should learn to develop research skills that are easy to understand and apply in higher education and learning and work activities. Likewise, academics and researchers in the pandemic era have limited space due to the government's policy response to the spread of COVID-19. In this phase, scholars and other researchers to continue working remotely. For all academicians to continue to carry out their duties during this pandemic crisis, they need to develop research skills, which we mentioned above is the Research Skills Development framework. Whereas with their research skills and insight, academics and other researchers can easily find approaches to problems in the implementation of all academic activities effectively and efficiently in this era, which is assisted by technological innovations in educational activities, especially the completion of learning and research assignments by all groups. On that basis, we consider the importance of research skills and development to be sharpened again with various research framework models for the university community and the wider community.

The authors observe that the development of research activities and results shows that the uptake of national 
studies output is still low in the international publication arena. So we understand that academics and researchers in general in Indonesia need to understand and apply the right approach to develop the research framework so that their research results can be improved. Therefore, we want to understand and prove the extent to which the Research Skills Development Framework supports academics and researchers working as they work remotely in an atmosphere of pandemic disruption. Because the research ability is da essential tool for the development and renewal of knowledge, especially in the college environment, this research skill is the most up-to-date method in the present $21^{\text {st }}$ century to uncover and understand the complexity of the problems of human life and business activities. Therefore, we are to examine the importance and benefits of the research development concept that we study in this paper. Later, we can make it easier to maintain scientific integrity when intellectuals must have the power to deny falsehood and uphold the truth of a significant problem facing academics and the community driving research development as initial capital to collect and analyze information very complex. (Macrina, 2014; Selgelid, 2006; Sikes and Gannon, 2011).
So the answer is an increase in research skills becomes absolute and cannot be negotiated in an era of progress, although it is still disturbed by the pandemic's impact. Another reason why the concept of developing a research framework is critical to discuss is that the concept of a research framework allows researchers and academics to have the opportunity to know the stages and steps of development research. This research stage will allow researchers to get the opportunity to learn from the initial steps, namely determining research objectives, data collection, data analysis, organizing, and communicating information or data that has structurally analyzed, evaluated, and accepted in the preparation of high standards - impact factors of the publication of research results. In other words, formulate questions, evaluate questions, process data, present results, and not forget about researchers' integrity aspects as modern scholars. With all the strengths and advantages of the RSD framework mentioned above, the authors would like to describe an easy way to understand the strengths of the Research Skills Development Framework to help researchers in Indonesia; maybe other researchers can work and learn remotely during the interruption of COVID-19. 


\section{LITERATURE REVIEW}

We present this paper to present the results of a review of the scientific paper output objectives from the study of the various uses and advantages of the RSD framework. This conceptual research framework is useful in developing research expertise among academics and other experts outside academia. As conceptual research that is not yet well-known among researchers and education practitioners in Indonesia, it is better to describe why this research framework is essential to understand for researchers or academics, including postgraduate students.

Understanding the RSD Framework according to its initiators, (Willison and O'Regan, 2007); (Putra et al., 2020), is a framework model for the development of academic research skills which is very useful in developing research skills of academics and researchers across disciplines and study programs. (Aslan, 2018; Aslan and Hifza, 2019; Aslan and Suhari, 2019; Aslan et al., 2020). This model of academic research framework initiated in 20017 at the University of Adelaide, South Australia. The advantage of this research framework adopted from Bloom Taxonomy is that it has equipped with a research rubric and an elaboration of researchers' or students' autonomy level when this framework application is research-based learning. This framework means that apart from being used as a framework for developing research skills, this research has a rubric matrix assessment function that automatically serves both things; learning and evaluation. Tractenberg et al., (2010) state the importance of a mastery rubric, which will guide the curriculum design and development to achieve course objectives. So it is as if there is learning, there will be assessment and Evaluation in Higher Education.

The rationale and relevance of this RSD framework in the current academic world are very appropriate if the research concept gets a place in an educational environment that prioritizes research activities in learning and completing assignments with a solution of the growth mindset research method. Besides, research such as RSD in education is essential because it contributes to the conception of this research in scientific development, increasing applications, and seeking and processing information based on reliable studies and policies. Therefore, academics and educator curriculum managers can use this framework to increase research capacity in the academic environment to increase competence. The teaching and learning process can continue to innovate. (Rahmawati et al., 2020). Likewise, according to Hinton et al., (2008), research involves thinking or 
cognition in learning that requires study and affective skills. So by combining the two domains, it will have implications for increasing research ability both during college and career practice in the world of work after graduation.

\section{Working in pandemic}

According toCrawford et al., (2020), since the COVID-19 hit the world, all educational activities from childhood education to adult education have been affected since the lockdown period to new regular days. However, through the UNESCO world education institute's direction, the online teaching and learning model is required, which is then adopted by the world community both in the teaching and learning process, examinations, and study and seminar activities held remotely. Like other educational activities, self-study and study activities certainly need a guide and framework to ensure continuity. Tuzovic and Kabadayi, (2020), stated that the impact of a pandemic on students and research had made a conceptual research framework and working agenda go flexibility and adaptable(Munjiat, 2020).

The pandemic's full condition is a valuable and relevant opportunity if the virtual study activities involve a proven and reputable RSD-like framework in various universities long before the outbreak. The intended purpose of applying this research concept is to make research activities easier in data search. Compiling in a measurable format achieves students' objectives and validity and other researchers' studies. This RSD research framework's value is to assist academics with practical concepts in teaching-learning and research activities that previously many students who worked did not have a framework foundation that explicitly took steps and study procedures in higher education during the pandemic crisis. So that with this framework, academics can build research skills from the initial process, the data analysis process until entering the final period of the reporting system with an evaluation rubric presentation as a standard guide, lecturers, and students and researchers self-guidance.

\section{METHOD}

This study's main objective was to describe some of the advantages and benefits of using a research skills development framework for researchers and academics working remotely during Indonesia's pandemic crisis. This paper will later explain how the advantages of the RSD framework can be convincing with empirical evidence from previous research findings. We assume that if the framework concept is applied in several countries, especially in Australia, especially the University of Adelaide, where this research is from, we also assume that Indonesian academics will also apply it in various final 
projects in academia and other industries. To facilitate this paper's problems, we first conducted a preliminary reading of the various literature on the conceptual framework's uses and advantages. After understanding, we tried to analyze and evaluate in-depth before we organized this study's results by following the same steps and stages in the research framework. (Willison, 2012; Hall et al., 2020; Finsterwalder and Kuppelwieser, 2020; Odekerken-Schröder et al., 2020). Because this research method adopts a qualitative application approach to phenomenological research, Vaismoradi et al., (2013), we also follow the content review method and thematic analysis, which has implications for the descriptive qualitative reporting process of social science, which also requires the principles of validity and reliability of findings.

\section{Projects on the RSD framework}

\section{Before the RSD initiation}

This study tried to diagnose the framework and plan to prepare proposals for developing research skills towards the Doctoral program project. This study focuses on developing good proposals that will succeed students with quality results through postgraduate supervisors and students with robust conceptual and pedagogical tools. The RSD Framework presents six aspects of the research process along the continuum of 'degrees of student autonomy.' This framework has been used successfully by lecturers to anticipate, develop, and assess undergraduate research skills towards a Doctoral Candidate. Thus this can provide a useful conceptual basis for Ph.D. supervision, which includes the supervision of students from different majors, international students who are directly studying in doctoral programs, students from undergraduate programs who do not explicitly develop RSD coherently, and qualitative and quantitative studies that need efficacy of proper framework. (Willison, 2012).

\section{After the RSD initiation}

The initiators wrote the first report on the use of the Research Skills Development Framework in 2008. They found that many universities in Australia, Canada, Ireland, and the Netherlands have started to take advantage of the RSD framework to guide the development of detailed and harmonious studies by prospective undergraduate and master's programs in various scientific majors. The research approach helped complete their final assignments and master project. (Willison and O’Regan, 2007).

The country's desire to develop and be strong as a society of knowledge and expertise will undoubtedly remain all nations' desire, and Ireland is no exception. It is possible if there is substantial guidance from the university. The third paper of the 
RSD framework introduces a research engineering model designed to conceptualize precisely the skill development type that allows enrolling students to the Higher Degree Research level to become ready to research. They are students, undergraduate, or postgraduate towards the world of work to gain research skills when entering employment. This RSD study's findings suggest more smallscale trials of this research model, evaluated and monitored thoroughly before this activity model directed into government policy. This time, it started developing a series of approaches to establish a more knowledge and expertise community. (Willison, 2009).

\section{The project was done collaboratively}

The next study is a Work Skills Development Framework or vocational, conducted to explain and evaluate student development in work-integrated learning packages starting from conceptualization to implementation. The research concept based on the development of research skills for this work is a model that allows higher education institutions to monitor student progress in a measured manner. This paper raises a study on the usefulness of a work research framework, especially for postgraduate students, focusing on the initiative, technological skills, lifelong learning skills, self-management, problemsolving and effective communication. All these skills articulation in five levels of autonomy will help users to apply them. This study's short story shows that working skill development often allows employers to quickly and meaningfully explore student performance in a range of nationally accredited employability skills. These findings included that students had a stronger sense of improvement in job skills after completing WIL than their employers, but both agreed that there was an increase, which varied with the specific skillset considered (Bandaranaike and Willison, 2010; Bandaranaike and Willison, 2015).

In the next study, the two initiators of this RSD framework considered the learning outcomes of 27 academics to thoughtfully develop and evaluate their research skills in 28 regular long semester courses. They researched subjects with small (17 participants) to medium-large (222 participants) from various engineering, economic, humanity majors, and interviewed 46 students one year after completing a course that developed research skills. They also interviewed 17 lecturers who were involved in developing and evaluating students' RSD research skills. Conclusive evidence that students develop a wide range of research skills from multiple disciplines. The students said that RSD's skills were beneficial for further studies and especially for 
assignments during college. Likewise, the lecturers showed that developing research and evaluation skills possessed by this rubric from RSD explicitly led to improving their teachings, such as helping lecturers explain lecture material objectives and more substantial feedback. Finally, the lecturers begin to change the paradigm of researching it is easy if students are familiar with a practical and useful framework (Willison, 2012).

\section{Project done by other scholars}

The third project undertaken by Venning and Buisman-Pijlman (2013), integrated a scoring system into a feedback loop in promoting the RSD framework in a postgraduate research program. They said the assessment system has focused on the choice of subjects that students choose. In essence, this paper raises the development and application of the primary assessment system to help student learning, especially in postgraduate studies at the University of Adelaide, where research weight is very high. The rubric that RSD has can explore the evaluation system matrix's capacity to improve the conceptual alignment between the course objectives and the learning outcomes when the matrix can be an integral part of providing feedback.

\section{Collaborative internationally}

Right in 2015, the RSD study investigated international postgraduate students' understanding of the framework. This study believes that learning success at the postgraduate level is related to students' understanding of this framework. Finally, some postgraduate students outside Australia have a relatively positive understanding of the benefits of the academic research framework, which has become useful research in postgraduate majors where research skills are the primary key to studying success. This finding is following the research objectives so that the conceptual framework classifying as a research framework that is very useful for lectures in educational schools. Therefore, it recommended that this research framework is disseminating into a research-based learning approach that is useful in improving student achievement at universities in Australia and universities abroad (Abdurrahman et al., 2017).

\section{Done outside Australian}

The development of research skills during college to develop research skills for work purposes has become a topic of study related to the RSD framework. This study emphasizes the transition of research skills and experience from college to research skills during employment and career development. However, although this transition period can be helped in college and during career experience or Work Integrated Learning, there is usually 
a gap between research skills taught in college and job skills requirements in the industry. Efforts to overcome these challenges faced by this period of integrity are significant to connect students with the future workforce's needs. So the results of this study, namely a review of the development of research skills during college, are a contribution to the pedagogy of integrated learning in the world of work, which has a direct application to the contribution of university educators to the development of student work patterns to link the gap between college and preparation for a career in industrial society (Bandaranaike, 2018; Abuzyarova et al., 2019).

This study demonstrated students' collaboration with lecturers and librarians with a model of developing research skills in reviewing book reviews. The author states that this study model is beneficial for faculty staff, students, and librarians in social sciences and humanities in rearranging book reviews based on 'scholarship as conversation' in library science. Next, the authors explain the origin of this unique collaborative process and document the impact of partnering academic staff, librarians, and students on improving academic research skills from book reviews. Collaborating in research skills development, digital information, and librarians, this article has identified many strategic opportunities for collaboration that make reviews more attractive and educational productively for students, academic staff, and librarians in the higher education context (Rowland et al., 2020).

\section{Done in Indonesia}

This study was conducted in Indonesia, which describes students' critical thinking skills through the RSD framework with case studies at the University of Indonesia, majoring in Biology. This study examines the integration of this research framework into the Biology course. It discusses how this framework can help academics develop students' critical thinking, especially on students' benefits and how to use the RSD framework to compile a full research-based lab report. With a questionnaire instrument, student open field questions, semi-structured interviews, and evaluation rubrics. The results illustrate two main benefits: students' self-understanding of critical thinking and a student laboratory reporting process appropriate to the RSD framework. So with these two descriptions, it indicated that this Australian framework of studies had proven its usefulness for academics (Mataniari et al., 2020).

\section{The understanding of the findings}

From the seven findings related to the RSD framework projects above, in response to the questions, this paper examined the benefits and helpful of the 
RSD framework for researchers working on remote systems during the COVID-19 response period in Indonesia. Among others, we can conclude that efforts to initiate the research framework for developing research skills towards the higher research program project are an initiative study before this framework was born in Australia in 2007. (Willison, 2006). Furthermore, after the framework inaugurating, various researchers and students were gradually involved in multiple research activities and learning, including several universities to collaborate in developing academic research. For example, as reported above, universities in Canada, the Netherlands, Ireland, and universities in Australia itself. In essence, based on this research concept's benefits and advantages, more and more parties are willing to cooperate. (Ain et al., 2019).

If we look at the progress of this conceptual research framework since first established. Now more parties are interested both from the evidence of the seven papers we reviewed above and other documents that have been, are being, and will be carried out and applied in many countries. Especially in western countries in the graduate program, especially the in context of higher education that prioritizes research development as an essential component, it is not wrong if the same story used as a guideline for the framework of developing academic research skills in Indonesia, especially the context of research work during the Covid-19 crisis with all the disturbances and obstacles to physical mobility.

\section{Implications of findings}

What is not less important in this study is to prove how many communities want to know necessary learning research frameworks such as RSD that is spreading across various developed countries. Academics in developed countries cannot refuse to be involved in scientific studies and academic and industrial-based studies based on the research framework's effectiveness and benefits. For example, as researchers in a pandemic period, we must have a comfortable and superior research framework for any research model. This research framework is useful for researchers searching for data, analyzing problems without boundaries of majors and disciplines. Furthermore, when a study requires a coherent and in-depth analysis effort on any topic, the results will be fast, accurate, the principles of flexibility, benefit, and acceleration of knowledge in academia and industry. Correlation with research learning and working preparation, Dias et al., (2013) describe a world apart between the actions and activities of writing in academia and the world of work. This paper offers uniqueness, writing assignments, and exam objectives as 
familiar and applied in the academic and career periods after graduating. They believe that various university programs and non-educational industries will synchronize the two worlds based on multi-site comparative studies over the years of writing.

With relevance to the development of RDS at the university level, Jackson, (2015), in his study of developing work skills, according to Jackson, that the current learning expectancy is education integration with work preparation after completing education. He added that the teaching world will face obstacles and twists and turns towards work readiness with the best possible effort. Based on the best evidence and study input, what students should remind of during the lecture period is the course program consistently between research theory and practice towards the correct application, which has implications for their academic results and future work professionalism. Likewise, Marzano, (2007) research builds background knowledge and expertise for academic excellence through various forms of successful research skills while still in college towards the world of work. To achieve this, he shows how education policy-making combines a carefully structured research skills enrichment program with two approaches sustainable research habituation and teaching how to complete in-depth research-based final semester assignments.

The reason is, the expertise or facets of RSD research allows researchers to identify problems, collect literature that can help answer problems, evaluate information sources to achieve quality, relevance, and produce practical solutions to problems that are the target of research so that it will be easy for researchers to communicate them formally according to publication standards. By engaging in various models of research frameworks such as RSD, researchers in the pandemic period will have research experience and allow researchers, especially postgraduate students, to have a sharper understanding of the problems studied, balance collaborative and innovative work in defining a research study journey and make it easier to start their career as researchers both in academia and in the industrial world outside the university. Another advantage is that through the evidence of the seven reviews above, it will allow researchers to gain more essential skills in completing the journey of scientific work based on the research mindset. (SpronkenSmith and Walker, 2010).

\section{Limitations of findings}

However, our research findings on the advantages of the RSD framework also have limitations that leave relevant issues for us to discuss in this section. This 
limitation is essential to understand in the context of method weaknesses and lack of support as provisions for conducting this research, from planning and processing to report writing. This finding can also determine the validity of the findings and possibly the credibility of the published results. Our findings address how many weaknesses and errors and a systematic review impact validity issues; this study requires direct input and guidance from the RSD proponent. Alternatively, it could be the sample review in the findings section we have selected; the method of exposure requires a statistical application. Alternatively, this finding could be because no previous studies have examined the Indonesian academic context, where the mindset of research is different from education in the western world, which is denser in lessons based on other study data. (Walker and Leary, 2009).

There may also be conflicts arising from this research because this research is a continuation of the project while the author was still in college. Therefore, it is necessary to acknowledge our recognition of this study's limitations to explain each rule in as much detail as possible without exaggerating the concise principle. The problem is why this study of the advantages of RSD emerged and how we provide reasonable answers using the methods we use to collect data, process, and report using a combination of qualitative and quantitative approaches to minimize this limitation.

\section{Recommendations}

By understanding the methods, findings, and discussion of this study's findings, it is appropriate that we propose several recommendations based on the results of our research, which we consider weak, so that later we can take specific actions to correct weaknesses and limitations. Therefore, in order for this study's implications to impact improving the findings, presenting recommendations is a concrete step that we propose to take towards the findings of this RSD framework study. So we can recommend the following: 1) Obtaining input from the right parties on assessing evidence of this research framework's usefulness and effectiveness; 2) Adding to an in-depth understanding of the advantages of this conceptual research framework for academics from universities who have not yet implemented studies as a core component of program teaching and evaluation systems; 3) Determine the optimal scale of the implementation of this research framework by analyzing how many academicians have involved themselves in research activities in the context of learning in tertiary institutions; 4) Further research states that the framework is genuinely relevant to use in 
the success of data study-based learning and mindset research-based learning environment.

\section{CONCLUSION}

The main point of this paper is how the paper published from the RSD Framework is a testament to the strength of this research framework for academics and other researchers working remotely during the COVID-19 outbreak in Indonesia. Do academics and researchers in this easy but challenging era question the usefulness of university-born research concepts with good leadership research? Inspiring research concepts are straightforward to understand. For example, the advantages include its introduction and the number of projects to be launched. Look at the enthusiasm of academics in countries that have successfully implemented this conceptual research to get academics and industry attention. To not misjudge the use and advantages of this framework, the following is a summary of the findings of this study. 1) Before creating the conceptual framework, a series of studies through publications and academic events.

2) After being formed, the research framework concept immediately received a response from universities outside Australia, especially among western universities whose academics were more on research and data. 3) More projects are underway through collaboration between universities by integrating research activities during college with studies on vocational needs after graduation, 4) The increasing number of projects undertaken by academics outside the university whose research framework is increasingly carrying out outside Australia, such as this study in Indonesia. 5) Apart from all, every year, the initiators of this research framework get grants and support from the Australian government on the grounds of the advantages and disadvantages they have in assisting and encouraging academics and alumni to successfully support government programs that require every education graduate to have research skills competency as an essential attribute of the Australian education framework.

\section{REFERENCES}

Abdurrahman, D., Willison, J., Sabir, F., 2017. International postgraduate students' perception of the research skill development framework. Natl. Conf. Teach. Prof. Conf. 1, 77-81.

Abuzyarova, D., Belousova, V., Krayushkina, Z., Lonshcikova, Y., Nikiforova, E., Chichkanov, N., 2019. The Role of Human Capital in Science, Technology and Innovation. Форсайт 13.

Ain, C.T., Sabir, F., Willison, J., 2019. Research skills that men and women developed at university and then used in workplaces. Stud. High. Educ. 44, 2346-2358. 
https://doi.org/10.1080/03075079 .2018 .1496412

Akkerman, S.F., Bakker, A., 2011. Boundary crossing and boundary objects. Rev. Educ. Res. 81, 132169.

Aslan, 2018. Dinamika Pendidikan Islam di Zaman Penjajahan Belanda. SYAMIL J. Pendidik. Agama Islam J. Islam. Educ. 6, 39-50. https://doi.org/10.21093/sy.v6i1. 1024

Aslan, Hifza, 2019. Kurikulum Pendidikan Masa Penjajahan Jepang Di Sambas. Edukasia Islam. 4, 171188.

https://doi.org/10.28918/jei.v4i2. 2295

Aslan, Hifza, Suhardi, M., 2020. DINAMIKA PENDIDIKAN ISLAM DI THAILAND PADA ABAD 19-20. Nazhruna J. Pendidik. Islam 3, 38-54. https://doi.org/10.31538/nzh.v3i1 .476

Aslan, Suhari, 2019. Sejarah Kurikulum Pendidikan Islam di Brunei Darussalam. J. Iqra Kaji. Ilmu Pendidik. 4, 113-127. https://doi.org/10.25217/ji.v4i1.4 48

Bandaranaike, S., 2018. From research skill development to work skill development. J. Univ. Teach. Learn. Pract. 15, 7.

Bandaranaike, S., Willison, J., 2015. Building capacity for workreadiness: Bridging the cognitive and affective domains.

Bandaranaike, S., Willison, J., 2010. Work skill development framework: An innovative assessment for work integrated learning.
Broekkamp, H., van Hout-Wolters, B., 2007. The gap between educational research and practice: A literature review, symposium, and questionnaire. Educ. Res. Eval. 13, 203-220.

Crawford, J., Butler-Henderson, K., Jurgen, R., Malkawi, B.H., Glowatz, M., Burton, R., Magni, P., Lam, S., 2020. COVID-19: 20 countries' higher education intraperiod digital pedagogy responses. J. Appl. Learn. Teach. 3. https://doi.org/10.37074/jalt.2020 .3.1.7

Dias, P., Freedman, A., Medway, P., Par, A., 2013. Worlds apart: Acting and writing in academic and workplace contexts. Routledge.

Finsterwalder, J., Kuppelwieser, V.G., 2020. Equilibrating resources and challenges during crises: a framework for service ecosystem well-being. J. Serv. Manag.

Hall, M.C., Prayag, G., Fieger, P., Dyason, D., 2020. Beyond panic buying: consumption displacement and COVID-19. J. Serv. Manag.

Hinton, C., Miyamoto, K., Della-Chiesa, B., 2008. Brain research, learning and emotions: implications for education research, policy and practice 1. Eur. J. Educ. 43, 87103.

Jackson, D., 2015. Employability skill development in work-integrated learning: Barriers and best practice. Stud. High. Educ. 40, 350-367.

Jongbloed, B., Enders, J., Salerno, C., 2008. Higher education and its communities: Interconnections, interdependencies and a research agenda. High. Educ. 56, 303-324. 
https://doi.org/10.1007/s10734008-9128-2

Macrina, F.L., 2014. Scientific integrity: Text and cases in responsible conduct of research. John Wiley \& Sons.

Mainardes, E.W., 2009. Competitive Advantages in Institutions of Higher Education: a Proposal of Research Model," Journal of Academy of Business and Economics Publisher. J. Acad. Bus. Econ. Publ. Int. Acad. Bus. Econ. Audience 9, 35-50.

Marzano, R.J., 2007. The art and science of teaching: A comprehensive framework for effective instruction. Ascd.

Mataniari, R., Willison, J., Hasibun, M.E., Sulistiyo, U., Fatria, D., 2020. Portraying Students' Critical Thinking Skills through Research Skill Development (RSD) Framework: A Case of a Biology Course in an Indonesian University. J. Turk. Sci. Educ. 17, 302-314.

Munjiat, S.M., 2020. Implementation of Islamic Religious Education Learning in Higher Education on The Pandemic Period. Nazhruna J. Pendidik. Islam 3, 285-295. https://doi.org/10.31538/nzh.v3i2 .757

Odekerken-Schröder, G., Mele, C., RussoSpena, T., Mahr, D., Ruggiero, A., 2020. Mitigating loneliness with companion robots in the COVID19 pandemic and beyond: an integrative framework and research agenda. J. Serv. Manag.

Putra, P., Mizani, H., Basir, A., Muflihin, A., Aslan, A., 2020. The Relevancy on Education Release Revolution
4.0 in Islamic Basic Education Perspective in Indonesia (An Analysis Study of Paulo Freire's Thought). Test Eng. Manag. 83, 10256-10263.

Rahmawati, Y., Ridwan, A., Faustine, S., Mawarni, $\quad$ P.C., 2020. Pengembangan Soft Skills Siswa Melalui Penerapan Culturally Responsive Transformative Teaching (CRT'T) dalam Pembelajaran Kimia. JPPIPA J. Penelit. Pendidik. IPA 6, 86-96.

Rowland, N.J., Knapp, J.A., Fargo, H., 2020. The collaborative book review as an opportunity for undergraduate research skill development. High. Educ. Res. Dev. 39, 577-590.

Selgelid, M.J., 2006. SCIENTIFIC INTEGRITY: TEXT AND CASES IN RESPONSIBLE CONDUCT OF RESEARCH. Blackwell Science Ltd.

Sikes, R.S., Gannon, W.L., 2011. Guidelines of the American Society of Mammalogists for the use of wild mammals in research. J. Mammal. 92, 235-253.

Spronken-Smith, R., Walker, R., 2010. Can inquiry-based learning strengthen the links between teaching and disciplinary research? Stud. High. Educ. 35, 723-740.

Tight, M., 2012. Researching higher education. McGraw-Hill Education (UK).

Tractenberg, R.E., Umans, J.G., McCarter, R.J., 2010. A mastery rubric: Guiding curriculum design, admissions and development of course objectives. Assess. Eval. High. Educ. 35, 15-32. 
Tuzovic, S., Kabadayi, S., 2020. The influence of social distancing on employee well-being: a conceptual framework and research agenda. J. Serv. Manag.

Vaismoradi, M., Turunen, H., Bondas, T., 2013. Content analysis and thematic analysis: Implications for conducting a qualitative descriptive study. Nurs. Health Sci. 15, 398405.

Walker, A., Leary, H., 2009. A problem based learning meta analysis: Differences across problem types, implementation types, disciplines, and assessment levels. Interdiscip. J. Probl.-Based Learn. 3, 6.

Willison, J., 2009. Development of all students' research skill becomes a knowledge society. Irel. J. High. Educ. 2.

Willison, J., 2006. A diagnostic and planning framework for research skill development toward the PhD proposal. Qual. Postgrad. Res. Knowl. Creat. Test. Times Part 2Proc. 281.

Willison, J., O’Regan, K., 2007. Commonly known, commonly not known, totally unknown: a framework for students becoming researchers. High. Educ. Res. Dev. 26, 393409.

https://doi.org/10.1080/07294360 701658609

Willison, J.W., 2012. When academics integrate research skill development in the curriculum. High. Educ. Res. Dev. 31, 905919. 